\title{
PENENTUAN INVESTASI BERDASARKAN TINGKAT RISIKO \\ PADA SAHAM SYARIAH, REKSADANA SYARIAH, DAN EMAS PERIODE 2011-20151]
}

\author{
Ayu Fitri \\ Mahasiswa Program Studi S1 Ekonomi Islam-Fakultas Ekonomi dan Bisnis-Universitas Airlangga \\ Email: ayu.fitri-13@feb.unair.ac.id \\ Dina Fitrisia Septiarini \\ Departemen Ekonomi Syariah-Fakultas Ekonomi dan Bisnis-Universitas Airlangga \\ Email: dina.fitrisia@feb.unair.ac.id
}

\begin{abstract}
The purpose of this study was to determine the difference of rate of risk on islamic stock, islamic mutual fund, and gold period 2011-2015. It uses quantitative approach by using Kruskal Wallis test. The sample collecting method used purposive sampling. This study was used secondary data that was collected from official websites of Indonesia Stock Exchange, PT BNP Paribas, and Price Gold. Data used was historical data from JII index, NAV per unit BNP Paribas Pesona Syariah, and gold price.

The result Kruskal-Wallis test show that there was significant difference of rate of risk on islamic stock, islamic mutual fund, and gold. But, when used Mann-Whitney next test show that there was no significant difference on Islamic stock. The result of this study proved that islamic stock was more best than gold and islamic mutual fund.
\end{abstract}

\section{Keywords: Rate of Risk, Islamic Stock, Islamic Mutual Fund, Gold.}

\section{PENDAHULUAN}

Muamalah merupakan sebagai aturanaturan Allah yang mengatur hubungan manusia dengan manusia dalam memdapat dan mengembangkan harta benda atau lebih tepatnya dapat dikatakan sebagai aturan Islam tentang kegiatan ekonomi yang dilakukan manusia (Abdullah, 2006:157). Kegiatan muamalah ini mengalami perkembangan pesat seiring dengan berkembangnya lembaga keuangan Islam di Indonesia.

Menurut data yang diperoleh membuktikan bahwa saham syariah mampu bersaing dengan instrumen lainnya seperti reksadana syariah dan emas (www.goldprice.org diakses, diakses pada tanggal 6 November 2016 dan www.idx.go.id, diakses pada tanggal 29 November 2016).

Bagi masyarakat yang beragama Islam, pemilihan jenis investasi harus sesuai dengan panduan yang disyariatkan dalam Al-Quran dan Hadits melalui proses screening. Proses tersebut bermanfaat bagi para investor yang menanamkan modalnya ke dalam investasi melalui tahap penyaringan dengan ketentuanketentuan yang tidak bertentangan dengan prinsip syariah.

Adapun kaidah figh pada tingkat pengembalian dan risiko menurut Djazuli (2006:124) sebagai berikut:

Alkhorō Ju Bị̣̂domānu<smiles>[As][As]=[As]</smiles>

"Manfaat suatu benda merupakan faktor pengganti kerugian"

1] Jurnal ini merupakan bagian dari skripsi Ayu Fitri, NIM: 041311433102 
Fitri, et al/Jurnal Ekonomi Syariah Teori dan Terapan Vol. 5 No.6 Juni 2018: 483-497; PENENTUAN INVESTASI BERDASARKAN TINGKAT RISIKO PADA SAHAM SYARIAH, REKSADANA SYARIAH, DAN EMAS PERIODE 2011-2015

Al Ghormu Bत Ghonmi الغَر مُبِا لغَنْم
"Risiko itu menyertai manfaat"
Kesimpulan dari kedua kaidah tersebut adalah return yang diperoleh harus sebanding dengan risiko yang didapat pada kerugian atas aset. Artinya, semakin tinggi risiko aset maka semakin tinggi pula tingkat return harapan dari aset tersebut (Tandelilin, 2010:12). Selain itu juga perlu melakukan perhitungan koefisien variasi apabila tingkat pengembalian (return) dan risiko pada instrumen investasi mendapatkan hasil yang sama (Hartono, 2013:262).

Berdasarkan latar belakang diatas, maka penelitian ini bertujuan untuk membandingkan tingkat risiko pada saham syariah, reksadana syariah, dan emas yang berguna bagi investor.

\section{Rumusan Masalah}

Latar belakang diatas menjadi acuan dalam penelitian ini, yaitu: "Apakah terdapat perbedaan tingkat risiko pada saham syariah, reksadana syariah, dan emas?"

\section{Tujuan Penelitian}

Tujuan dari penelitian ini adalah untuk mengetahui perbedaan tingkat risiko pada saham syariah, reksadana syariah, dan emas.

\section{LANDASAN TEORI}

Investasi merupakan penanaman modal untuk satu atau lebih aktiva yang dimiliki dan biasanya berjangka waktu lama dengan harapan mendapatkan keuntungan di masa-masa yang akan datang (Sunariyah, 2003:4). Sedangkan menurut Simamora (2000:438), investasi adalah suatu aktiva yang digunakan oleh perusahaan dalam memperkaya melalui distribusi hasil investasi (seperti pendapatan bunga, royalty, dividen, pendapatan sewa, dan lain-lain), untuk apresiasi nilai investasi, atau manfaat yang diperoleh melalui perdagangan. Kedua pengertian mengacu pada tujuan untuk memperoleh keuntungan di masa mendatang melalui perdagangan.

Tujuan investasi menurut Imam (2008:10) secara umum dapat dibagi menjadi tujuan jangka pendek dan tujuan jangka panjang. Tujuan jangka pendek berada dalam rentang waktu antara 1-2 tahun kedepan. Contohnya, ketika menginginkan renovasi rumah dengan furniture tipe baru. Sedangkan tujuan jangka panjang yang memiliki rentang waktu 5 tahun atau lebih. Contohnya, mempersiapkan dana pensiun, biaya pendidikan untuk anak sekolah, dan lainlain.

Khalifah Umar pernah menyuruh kaum Muslimin dengan mengatakan: "Siapa saja yang memiliki vang, hendaklah ia menginvestasikannya dan siapa saja yang memiliki tanah hendak ia menanaminya" (Hidayat, 2011:24). Arti dalam landasan tersebut adalah kegiatan berinvestasi sangat dianjurkan bagi manusia demi memenuhi konsep kekayaan dan pengguna kekayaan.

Menurut Hartono (2003:132) Jakarta Islamic Index (JII) merupakan indeks yang berisi dengan 30 saham perusahaan yang 
Fitri, et al/Jurnal Ekonomi Syariah Teori dan Terapan Vol. 5 No.6 Juni 2018: 483-497; PENENTUAN INVESTASI BERDASARKAN TINGKAT RISIKO PADA SAHAM SYARIAH, REKSADANA SYARIAH, DAN EMAS PERIODE 2011-2015

memenuhhi kriteria investasi berdasarkan

syariat Islam. Hal ini sekaligus menjadi alasan untuk memilih JII pada penelitian

ini. Berikut prosedur-prosedur JII, yaitu:

a. Saham dipilih harus sudah tercatat kurang lebih 30 bulan terakhir, kecuali saham yang termasuk kapitalisasi besar.

b. Mempunyai rasiio utang terhadap aktiva tidak lebih dari $90 \%$ di laporan keuangan tahunan atau tengah tahun.

c. Dipilih 60 saham dengan urutan ratarata kapitalisasi pasar terbesar selama satu tahun terakhir.

d. Dipilih lagi 30 saham dengan urutan tingkat likuiditas rata-rata nilai perdaganngan selama satu tahun terakhir.

Tujuan investor berinvestasi pada saham syariah untuk mengharapkan tingkat pengembalian yang tinggi. Tingkat pengembalian (return) saham menurut Brigham dan Houston (2006:215) yaitu selisih antara jumlah yang diterima dengan jumlah yang diinvestasikan.

Investor yang menginginkan return tinggi pada investasi saham syariah harus bersiap menghadapi risiko yang tinggi. Menurut Tandelilin (2010:104) mengatakan bahwa terdapat dua jenis risiko dalam investasi saham syariah, yaitu:

a. Systematic Risk, risiko yang berkaitan dengan perubahan pasar secara keseluruhan (perubahan tingkat suku bunga, kurs valuta asing, dan kebijakan pemerintah). b. Unsystematic Risk, risiko yang tidak berkaitan dengan perubahan pasar secara keseluruhan (struktur modal, struktur aset, tingkat likuiditas, dan tingkat keuntungan).

Instrumen investasi lainnya yang ada pada penelitian ini, yaitu reksadana syariah. Menurut Fatwa Dewan Syariah Nasional Nomor 20/DSN-MUI/IV/2001 menyatakan bahwa reksadana yang beroperasi menurut ketentuan dan prinsip Syariah Islam, baik dalam bentuk akad antara pemodal sebagai pemilik harta (shahib al-mal/Rabb al Mal) dengan manajer investasi sebagai wakil shahib almal, antara wakil shahib al-mal, maupun antara manajer investasi sebagai wakil shahib al-mal dengan pengguna investasi.

Tujuan utama bagi para investor dalam berinvestasi adalah harapan return yang tinggi. Salah satu investasi dengan return yang tinggi dan tidak menyimpang dari Al-Qur'an dan Hadits adalah reksadana syariah. Investor dapat membeli reksadana syariah tersebut dari sebuah perusahaan investasi pada harga per saham atau per unit penyertaan yang nilainya bergantung pada besarnya nilai aktiva bersih (NAB) per unit (Tandelillin, 2010:50)

$$
N A B=\frac{\text { Jumlah Aset }- \text { Total Kewajiban }}{\text { Jumlah Unit Penyertaan }} \text { (2.1) }
$$

Hal yang perlu diingat bahwa semua jenis instrumen investasi pasti terdapat risiko. Reksadana syariah juga tergolong investasi yang berisiko rendah pulatergantung jenis reksadana syariah yang dipilih. Menurut Achsien (2000:82) 
Fitri, et al/Jurnal Ekonomi Syariah Teori dan Terapan Vol. 5 No.6 Juni 2018: 483-497; PENENTUAN INVESTASI BERDASARKAN TINGKAT RISIKO PADA SAHAM SYARIAH, REKSADANA SYARIAH, DAN EMAS PERIODE 2011-2015

menyatakan ada beberapa macam risiko

tiba harga melonjak naik dan bisa juga pada reksadana syariah, yaitu:

a. Risiko politik dan ekonomi

b. Risiko pasar

c. Risiko inflasi

d. Risiko nilai tukar

e. Risiko spesifik

f. Risiko menurunnya NAB

g. Risiko likuiditas

Salah satu jenis investasi yang sedang diminati oleh masyarakat adalah emas. Tahun 1972, konversi dolar terhadap emas adalah US\$35 sama dengan 1 (satu) troy ounce emas atau 28,35 gram emas (Judisseno, 2005:36). Tetapi untuk tahun 2016 ini, 1 (satu) troy ounce emas menjadi 31,1035 gram emas (www.kitco.com diakses tanggal 29 November 2016). Harga emas dunia saat ini dalam IDR sebesar Rp 516.780 per gram dan dalam IDR Rp 16.073.665 per troy ounce emas (harga-emas.org diakses tanggal 29 November 2016).

Emas merupakan media investasi yang kemungkinan besar tidak akan terkena dampak inflasi (Dipraja, 2011:21). Fatwa Dewan Syariah Nasional Nomor 77/DSN-MUI/VI/2010 menyatakan bahwa seringkali transansaksi jual beli emas yang dilakukan masyarakat saat ini dengan cara pembayaran tidak tunai, baik secara angsuran (taqsith) maupun secara tangguh (ta'jil).

Namun, Rasulullah SAW melarang melakukan kegiatan tersebut karena proses yang dilakukan akan menimbulkan riba. Riba dalam kategori ini ditunjukkan pada saat mulai mengangsur secara tibaharga melonjak turun. Tetapi ada kaidah figh yang menyatakan "Hukum yang didasarkan pada adat (kebiasaan) berlaku bersamaa adat tersebut dan batal (tidak berlaku) bersamanya ketika adat itu batal, seperti mata vang dalam muamalat" (Al-Qarafi, 2009:228).

Investasi emas merupakan salah satu upaya untuk mendapatkan keuntungan yang lebih banyak dengan dana investasi sedikit (Salim, 2010:88). Terdapat tingkat pengembalian emas menurut Tanuwidjaja (2009:28-29), diantaranya:

a. Investasi yang stabil dan nilainya terus meningkat.

b. Mengamankan nilai kekayaan akibat inflasi.

c. Perlindungan nilai aset dari gejolak nilai tukar rupiah.

Berinvestasi dalam bentuk emas cenderung memiliki risiko yang rendah. Salah satu risiko yang dapat diketahui adalah fluktuasi harga emas. Risiko investasi emas menurut Handayani (2010:162), yaitu:

a. Tidak memperoleh dividen atau penghasil rutin dari investasi emas.

b. Tidak praktis disimpan karena membutuhkan ruang tersendiri untuk menyimpan.

c. Jika investasi tersebut berupa perhiasan, maka membutuhkan biaya perawatan emas.

d. Mengalami penyusutan ketika disimpan atau digunakan dalam jangka waktu yang lama. 
Fitri, et al/Jurnal Ekonomi Syariah Teori dan Terapan Vol. 5 No.6 Juni 2018: 483-497; PENENTUAN INVESTASI BERDASARKAN TINGKAT RISIKO PADA SAHAM SYARIAH, REKSADANA SYARIAH, DAN EMAS PERIODE 2011-2015

Tujuan utama orang berinvestasi yaitu memperoleh harapan pengembalian keuntungan yang dirasakan di masa yang akan datang. Hartono (2013:109) membedakan return menjadi dua, yaitu return realized dan expected return. Return realized merupakan return return yang telah terjadi dengan menggunakan data historis sebagai salah satu pengukur return dan risiko perusahaan. Sedangkan expected return merupakan return yang diharapkan oleh investor dimasa mendatang dan bersifat belum terjadi.

Perhitungan dengan menggunakan pengukuran return realized pada persamaan 2.2 yang ditunjukkan oleh Hartono (2013:236) yang digunakan dalam penelitian berupa return harian.

$$
\mathrm{R}_{\mathrm{it}}=\frac{P_{t}-P_{t-1}}{P_{t-1}}
$$

Keterangan:

$\mathrm{R}_{\text {it }} \quad=$ return instrumen investasi

$\mathrm{P}_{\dagger} \quad=$ harga instrumen investasi pada bulan ke- $\dagger$

$\mathrm{P}_{\dagger-1}=$ harga instrumen investasi pada sebelum bulan ke- $\uparrow$

Sedangkan pada pengukuran expected return pada persamaan 2.3 yang dikemukakan oleh Hartono (2013:253)

$$
E\left(R_{i}\right)=\sum^{n} \frac{R i}{-}
$$

Keterangan:

$$
\begin{aligned}
E\left(R_{i}\right)= & \text { return ekspektasi (expected return) } \\
& \text { instrumen investasi } \\
R_{i} \quad= & \text { return instrumen investasi } \\
n \quad= & \text { periode investasi }
\end{aligned}
$$

Membicarakan perihal investasi, tidak cukup bila menghitung returnnya saja tetapi juga harus mempertimbangkan risiko yang akan dihadapi karena kedua perhitungan tersebut merupakan satu kesatuan yang tidak dapat dipisahkan. Menurut Brigham dan Houston (2001:230) risiko merupakan bahaya, petaka, kemungkinan mengalami kerugian atau kerusakan.

Perbedaan harapan mencerminkan simpangan yang biasanya menggunakan metode pengukuran standar deviasi (simpangan baku) pada persamaan 2.4. Menurut Guinan (2010:339) standar deviasi merupakan ukuran statistik yang membantu menjelaskan sejarah volatilitas investasi.

$\sigma_{\mathrm{i}}$

$$
\sqrt{n}\left[\left(R_{i t}-E(R i)\right)\right.
$$

Keterangan:

$\sigma_{\mathrm{i}} \quad=$ standar deviasi instrumen investasi

$\mathrm{n} \quad=$ periode investasi

$E\left(R_{i}\right)=$ return ekspektasi (expected return) instrumen investasi

$\mathrm{R}_{\mathrm{it}} \quad=$ return instrumen investasi

Jika terdapat dua investasi yang memiliki return sama dengan risiko berbeda, maka investasi yang dipilih oleh para investor adalah investasi dengan risiko yang lebih rendah meskipun return sama. Demikian pula dengan risiko sama dengan return berbeda, maka para investor cenderung memilih return lebih tinggi meskipun risiko yang akan dihadapi sama. Namun, ketika menjumpai dua investasi yang memiliki return sama 
Fitri, et al/Jurnal Ekonomi Syariah Teori dan Terapan Vol. 5 No.6 Juni 2018: 483-497; PENENTUAN INVESTASI BERDASARKAN TINGKAT RISIKO PADA SAHAM SYARIAH, REKSADANA SYARIAH, DAN EMAS PERIODE 2011-2015

dengan risiko sama, maka perlu

Tingkat risiko didapatkan dari menghitung koefisien variasi dari masingmasing investasi.

Hubungan antara expected return dengan risiko dapat dilihat pada gambar 2.1 .

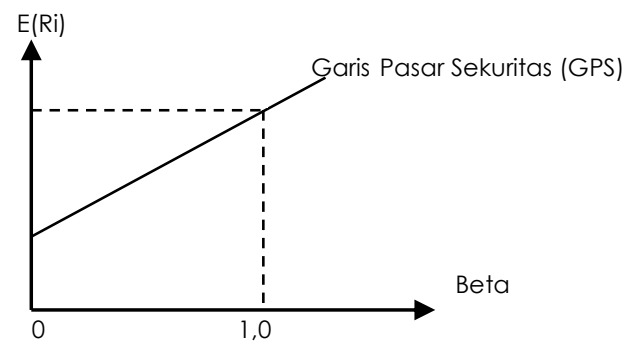

Sumber: Hartono. 2013. Teori Portofolio dan Analisis Investasi. Edisi kedelapan. Hal. 528. Yogyakarta: BPFE.

Gambar 2.1

Trade Off Return dan Risiko

Pehitungan koefisen variasi yang digunakan adalah data historis dalam persamaan 2.5 .

$$
\mathrm{CV}=\frac{\sigma_{\mathrm{i}}}{\mathrm{E}(\mathrm{Ri})}
$$

Keterangan:

$\mathrm{CV}=$ koefisien variasi

$\sigma_{\mathrm{i}} \quad=$ standar deviasi instrumen investasi

$E\left(R_{i}\right)=$ return ekspektasi (expected return) instrumen investasi

Semakin kecil nilai koefisien variasi menunjukkan aktiva semakin baik tersebut dan semakin kecil koefisien variasi menunjukkan semakin kecil risiko dan semakin besar return ekspektasi (Hartono, 2013:262-263).

Rumusan masalah, tujuan penelitian, landasan teori dapat memunculkan hipotesis dalam penelitian ini, yaitu: "Terdapat perbedaan signifikan antara tingkat risiko pada saham syariah, reksadana syariah, dan emas".

perhitungan return realized, expected return, risiko, dan koefisien variasi masingmasing instrumen investasi. Untuk perhitungan expected return, risiko, dan koefisien variasi dapat dilihat pada model persamaan 2.3, persamaan 2.4, persamaan 2.5. Berikut model persamaan return realized dari masing-masing instrumen investasi:

1. Return Realized Saham Syariah

$$
\text { Rsaham syariah }=\frac{\text { Indeks Harga } \mathrm{t}-\text { Indeks Harga }_{\mathrm{t}-1}}{\text { Indeks Harga }_{\mathrm{t}-1}}
$$

2. Return Realized Reksadana Syariah

$$
\begin{aligned}
& \text { RReksadana Syariah } \\
& \frac{\text { NAB per Unit }}{t}-\text { NAB per Unit }_{t-1} \\
& \text { NAB per Unit } \text { t }_{t-1}
\end{aligned}
$$

3. Return Realized Emas

$$
R_{E m a s}=\frac{\text { Harga Emas }}{t-\text { Harga Emast }_{t-1}}
$$

\section{METODOLOGI PENELITIAN}

\section{Pendekatan Penelitian}

Penelitian ini menggunakan pendekatan kuantitatif agar penelitian ini dapat menghasilkan kesimpulan yang akurat.

\section{Identifikasi Variabel}

Variabel yang digunakan adalah return, risiko, dan koefisien variasi.

\section{Definisi Operasional}

Definisi operasional mengenai variabel-variabel yang digunakan dalam penelitian ini, yaitu:

a. Tingkat Pengembalian (Return)

Return adalah imbalan atas keberanian investor menanggung risiko atas investasi yang dilakukannya (Tandelilin, 2001:102). Data return berasal dari indeks harga pembukaan Jakarta 
Fitri, et al/Jurnal Ekonomi Syariah Teori dan Terapan Vol. 5 No.6 Juni 2018: 483-497; PENENTUAN INVESTASI BERDASARKAN TINGKAT RISIKO PADA SAHAM SYARIAH, REKSADANA SYARIAH, DAN EMAS PERIODE 2011-2015

Islamic Index (JII), NAB per unit reksadana merupakan data rasio dan bersifat time pesona syariah, dan harga emas tahun 2011-2015 ini merupakan data rasio dan bersifat time series. Untuk menghitung return terdapat dua cara, yaitu return realized dan expected return. Return realized yang digunakan pada penelitian ini adalah return harian selama 5 tahun (2011-2015) sesuai dengan persamaan 2.6 (saham syariah), persamaan 2.7 (reksadana syariah), dan persamaan 2.8 (emas). Sedangkan untuk menentukan expected return dapat diperoleh dari hasil rata-rata return realized instrumen investasi harian tahun 2011-2015 dengan menggunakan persamaan 2.3.

b. Risiko

Risiko merupakan kebalikan dari expected return dengan return realized terhadap instrumen investasi (Tandelilin, 2001:48). Penelitian ini menggunakan pengukuran risiko yaitu standar deviasi. Data risiko dapat diperoleh dari expected return instrumen investasi bulanan tahun 2011-2015 dengan menggunakan persamaan 2.4 yang merupakan data rasio dan bersifat time series.

c. Koefisien Variasi

Koefisien variasi merupakan ukuran penyimpangan relatif dari suatu distribusi sebagai rasio standar deviasi dengan nilai yang diperkirakan untuk nilai distribusi tersebut (Horne dan Wachowicz, 2007:79). Data koefisien variasi dapat diperoleh dari expected return dan risiko pada instrumen investasi bulanan tahun 2011-2015 dengan menggunakan persamaan 2.5 yang series.

\section{Jenis dan Sumber Data}

Jenis data yang digunakan dalar 489 penelitian ini adalah data sekunder yany dapat diakes melalui www.idx.co.id, PT BNP Paribas, dan www.goldprice.org serta diperoleh dari beberapa sumber litelatur lainnya yang berkaitan dengan penelitian ini.

\section{Populasi dan Sampel}

Penelitian ini menggunakan populasi indeks saham syariah yaitu Jakarta Islamic Index (JII), reksadana syariah jenis reksadana pesona syariah, dan emas dari PT Antam Tbk. periode 2011-2015.

Penelitian ini menggunakan metode pengambilan sampel non probabilitas dengan kategori purposive sampling. Menurut Sugiyono (2011:84) purposive sampling yaitu tipe penarikan sampel dengan pertimbangan tertentu.

\section{Teknik Analisis Data}

Teknik analisis yang digunakan adalah Kruskal-Wallis. Berikut langkah-langkahnya:

1. Menghitung rasio-rasio Jakarta Islamic Index (JII), NAB per unit BNP Paribas Pesona Syariah, dan harga emas dalam penelitian ini.

2. Menggunakan uji normalitas dengan menggunakan Kolmogorov-Smirnov dengan tingkat signifikansi atau nilai probabilitas $5 \%$. Pengujian normalitas ini untuk mengetahui apakah data yang diperoleh memiliki distribusi normal atau tidak sehingga dapat dipakai dalam melakukan uji beda (parametrik atau non parametrik). 
Fitri, et al/Jurnal Ekonomi Syariah Teori dan Terapan Vol. 5 No.6 Juni 2018: 483-497; PENENTUAN INVESTASI BERDASARKAN TINGKAT RISIKO PADA SAHAM SYARIAH, REKSADANA SYARIAH, DAN EMAS PERIODE 2011-2015

3. Uji beda dengan menggunakan ANOVA untuk data yang memiliki distribusi normal dan uji Kruskal-Wallis untuk data yang tidak terdistribusi normal.

\section{HASIL DAN PEMBAHASAN}

Metode pengambilan sampel non probabilitas dengan kategori purposive sampling antara JII, NAB per unit BNP Paribas Pesona Syariah, dan harga emas.

Setelah pengumpulan data selesai maka langkah selanjutnya adalah menghitung return realized berdasarkan data historis harian yang dikumpulkan. Kemudian hasil tersebut dirata-rata sehingga menjadi data historis bulanan yang menghasilkan perhitungan expected return, risiko, dan koefisien variasi. Peritungan tersebut digunakan untuk membandingkan saham syariah, reksadana syariah, dan emas.

\section{Analisis Deskriptif}

Tabel 4.1

Statistik Deskriptif

\begin{tabular}{|c|c|c|c|c|c|}
\hline & $\begin{array}{l}\text { Instrumen } \\
\text { Investasi }\end{array}$ & $\mathbf{N}$ & Min. & Maks. & Mean \\
\hline \multirow{3}{*}{ Return } & JII & 60 & $-0,090$ & 0,080 & 0,00353 \\
\hline & $\begin{array}{c}\text { Reksadana } \\
\text { Pesona } \\
\text { Syariah }\end{array}$ & 60 & $-0,005$ & 0,004 & 0,00024 \\
\hline & $\begin{array}{l}\text { Instrumen } \\
\text { Investasi }\end{array}$ & $\mathbf{N}$ & Min. & Maks. & Mean \\
\hline Refurn & Emas & 60 & $-0,058$ & 0,106 & 0,00485 \\
\hline \multirow{3}{*}{ Risiko } & JII & 60 & 0,007 & 0,0087 & 0,03653 \\
\hline & $\begin{array}{c}\text { Reksadana } \\
\text { Pesona } \\
\text { Syariah }\end{array}$ & 60 & 0,004 & 0,027 & 0,01124 \\
\hline & Emas & 60 & 0,004 & 0,098 & 0,02629 \\
\hline \multirow{3}{*}{$\begin{array}{c}\text { Koefisien } \\
\text { Variasi }\end{array}$} & JII & 60 & $-5,453$ & 4,812 & 0,18168 \\
\hline & $\begin{array}{c}\text { Reksadana } \\
\text { Pesona } \\
\text { Syariah }\end{array}$ & 60 & $\begin{array}{c}- \\
33,932\end{array}$ & 126,545 & 4,83952 \\
\hline & Emas & 60 & $-4,423$ & 16,624 & 00,19893 \\
\hline
\end{tabular}

Sumber: Data diolah

Nilai rata-rata tertinggi tingkat pengembalian pada instrumen investasi ini dimiliki oleh emas sebesar 0,00485. Instrumen investasi dengan nilai tertinggi

ditunjukkan pada emas sebesar 0,106. Sedangkan untuk nilai terendah ditunjukkan pada Jll sebesar 0,090. Ratarata terendah yaitu pada reksadana syariah sebesar 0,00024.

Hasil perhitungan tingkat pengembalian ini dapat disimpulkan bahwa emas merupakan pilihan investasi yang paling menguntungkan karena tingkat pengembalian yang akan didapatkan paling tinggi.

Nilai rata-rata tertinggi risiko pada instrumen investasi ini dimiliki oleh JII sebesar 0,03653. Instrumen investasi dengan nilai tertinggi ditunjukkan pada emas sebesar 0,098 . Sedangkan untuk nilai terendah ditunjukkan pada reksadana syariah dan emas sebesar 0,004. Rata-rata terendah yaitu pada reksadana syariah sebesar 0,01124.

Sehingga hasil risiko ini dapat disimpulkan bahwa reksadana syariah merupakan pilihan investasi paling menguntungkan karena risiko yang akan dihadapi paling kecil.

Nilai rata-rata tertinggi koefisien variasi pada instrumen investasi ini dimiliki oleh reksadana syariah sebesar 4,83952. Instrumen investasi dengan nilai tertinggi dan terendah dari koefisien variasi juga dimiliiki oleh reksadana syariah sebesar 126,545 dan -33,932. Sedangkan untuk rata-rata terendah yaitu pada JII sebesar 0,18168 .

Sehingga hasil perhitungan koefisien variasi ini dapat disimpulkan bahwa JII merupakan pilihan investasi paling menguntungkan karena semakin kecil 
Fitri, et al/Jurnal Ekonomi Syariah Teori dan Terapan Vol. 5 No.6 Juni 2018: 483-497; PENENTUAN INVESTASI BERDASARKAN TINGKAT RISIKO PADA SAHAM SYARIAH, REKSADANA SYARIAH, DAN EMAS PERIODE 2011-2015

koefisien variasi maka semakin besar keuntungan yang diharapkan dari investasi tersebut.

\section{Uji Normalitas}

Tabel 4.2

Hasil Uji Normalitas Kolmogorov Smirnov

\begin{tabular}{|c|c|c|c|c|}
\hline & $\begin{array}{l}\text { Instrumen } \\
\text { Investasi }\end{array}$ & Sig. & Keterangan & Pengujian \\
\hline \multirow{3}{*}{ Return } & JII & 0,041 & $\begin{array}{c}\text { Tidak } \\
\text { terdistribusi } \\
\text { normal }\end{array}$ & $\begin{array}{c}\text { Kruskal- } \\
\text { Wallis }\end{array}$ \\
\hline & $\begin{array}{c}\text { Reksadana } \\
\text { Pesona } \\
\text { Syariah } \\
\end{array}$ & 0,015 & $\begin{array}{c}\text { Tidak } \\
\text { terdistribusi } \\
\text { normal }\end{array}$ & $\begin{array}{l}\text { Kruskal- } \\
\text { Wallis }\end{array}$ \\
\hline & Emas & 0,051 & $\begin{array}{c}\text { Terdistribusi } \\
\text { normal }\end{array}$ & ANOVA \\
\hline \multirow{3}{*}{ Risiko } & JII & 0,023 & $\begin{array}{c}\text { Tidak } \\
\text { terdistribusi } \\
\text { normal }\end{array}$ & $\begin{array}{l}\text { Kruskal- } \\
\text { Wallis }\end{array}$ \\
\hline & $\begin{array}{c}\text { Reksadana } \\
\text { Pesona } \\
\text { Syariah }\end{array}$ & 0,000 & $\begin{array}{c}\text { Tidak } \\
\text { terdistribusi } \\
\text { normal }\end{array}$ & $\begin{array}{c}\text { Kruskal- } \\
\text { Wallis }\end{array}$ \\
\hline & Emas & 0,002 & $\begin{array}{c}\text { Tidak } \\
\text { terdistribusi } \\
\text { normal }\end{array}$ & $\begin{array}{c}\text { Kruskal- } \\
\text { Wallis }\end{array}$ \\
\hline \multirow{3}{*}{$\begin{array}{c}\text { Koefisien } \\
\text { Variasi }\end{array}$} & JII & 0,000 & $\begin{array}{c}\text { Tidak } \\
\text { terdistribusi } \\
\text { normal }\end{array}$ & $\begin{array}{l}\text { Kruskal- } \\
\text { Wallis }\end{array}$ \\
\hline & $\begin{array}{c}\text { Reksadana } \\
\text { Pesona } \\
\text { Syariah }\end{array}$ & 0,000 & $\begin{array}{c}\text { Tidak } \\
\text { terdistribusi } \\
\text { normal } \\
\end{array}$ & $\begin{array}{l}\text { Kruskal- } \\
\text { Wallis }\end{array}$ \\
\hline & Emas & 0,000 & $\begin{array}{c}\text { Tidak } \\
\text { terdistribusi } \\
\text { normal }\end{array}$ & $\begin{array}{l}\text { Kruskal- } \\
\text { Wallis }\end{array}$ \\
\hline
\end{tabular}

Sumber: Data diolah

Berdasarkan tabel 4.2 menunjukkan bahwa JII, reksadana syariah, dan emas dari tingkat pengembalian, risiko, dan koefisien variasi tidak terdistribusi normal kecuali emas dan JII pada tingkat pengembalian berdistribusi normal. Hal ini dapat disimpulkan bahwa pengujian tingkat risiko selanjutnya menggunakan uji Kruskal-Wallis. Apabila pengujian tersebut menyatakan $\mathrm{H}_{0}$ ditolak maka perlu melakukan uji lanjut yaitu Mann Whitney.

\section{Tabel 4.3}

Hasil Uji Kruskal-Wallis

\begin{tabular}{|c|c|c|c|c|c|}
\hline & $\begin{array}{l}\text { Instrumen } \\
\text { Investasi }\end{array}$ & $\begin{array}{c}\text { Mean } \\
\text { Rank }\end{array}$ & $\begin{array}{c}\text { Chi- } \\
\text { Square }\end{array}$ & Df & Sig. \\
\hline \multirow{3}{*}{ Return } & JII & 99,72 & \multirow{3}{*}{2,822} & \multirow{3}{*}{2} & \multirow{3}{*}{0,244} \\
\hline & $\begin{array}{c}\text { Reksadana } \\
\text { Pesona } \\
\text { Syariah }\end{array}$ & 85,72 & & & \\
\hline & Emas & 86,06 & & & \\
\hline \multirow{3}{*}{ Risiko } & JII & 123,58 & \multirow{3}{*}{55,699} & \multirow{3}{*}{2} & \multirow{3}{*}{0,000} \\
\hline & $\begin{array}{c}\text { Reksadana } \\
\text { Pesona } \\
\text { Syariah }\end{array}$ & 53,00 & & & \\
\hline & Emas & 94,92 & & & \\
\hline
\end{tabular}

\begin{tabular}{|c|c|c|c|c|c|}
\hline \multirow[b]{2}{*}{$\begin{array}{c}\text { Koefisien } \\
\text { Variasi }\end{array}$} & JII & 86,32 & \multirow{3}{*}{10,495} & \multirow{3}{*}{2} & \multirow{3}{*}{0,000} \\
\hline & $\begin{array}{l}\text { Reksadana } \\
\text { Pesona } \\
\text { Syariah }\end{array}$ & 107,57 & & & \\
\hline & Emas & 77,61 & & & \\
\hline
\end{tabular}

Sumber: Data diolah

Perbandingan Tingkat Pengembalian (Return) pada Saham Syariah, Reksadana Syariah, dan Emas Periode 2011-2015

Berdasarkan tabel 4.3 nilai signifikansi tingkat pengembalian (return) pada JII, reksadana syariah, dan emas sebesar 0,244 lebih besar dari 0,05. Hal ini menyatakan bahwa tingkat pengembalian pada JII, reksadana syariah, dan emas tidak terdapat perbedaan yang signifikan.

Statistik hitung atau chi-square sebesar 2,822 dan memiliki derajat kebebasan (df) sebesar 2 dengan tingkat signifikansi sebesar 0,05 . Dengan melihat nilai chisquare, derajat kebebasan, dan tingkat signifikansi tersebut maka dalam statistk tabel menunjukkan angka sebesar 5,991. Keputusan uji Kruskal-Wallis dari tingkat pengembalian pada instrumen investasi adalah $\mathrm{H}_{0}$ diterima. Keputusan tersebut dapat dilihat dari nilai statistik hitung lebih kecil dari tabel statistik $(2,882<5,991)$.

Perbandingan Risiko pada Saham Syariah, Reksadana Syariah, dan Emas Periode 2011-2015

Berdasarkan tabel 4.3 nilai signifikansi risiko pada JII, reksadana syariah, dan emas sebesar 0,000 lebih kecil dari 0,05. Hal ini menyatakan bahwa risiko pada JII, reksadana syariah, dan emas terdapat perbedaan yang signifikan.

Statistik hitung atau chi-square sebesar 55,699 dan memiliki derajat kebebasan (df) sebesar 2 dengan tingkat signifikansi sebesar 0,05. Dengan melihat nilai chi- 
Fitri, et al/Jurnal Ekonomi Syariah Teori dan Terapan Vol. 5 No.6 Juni 2018: 483-497; PENENTUAN INVESTASI BERDASARKAN TINGKAT RISIKO PADA SAHAM SYARIAH, REKSADANA SYARIAH, DAN EMAS PERIODE 2011-2015

square, derajat kebebasan, dan tingkat signifikansi tersebut maka dalam statistk tabel menunjukkan angka sebesar 5,991. Keputusan uji Kruskal-Wallis dari tingkat pengembalian pada instrumen investasi adalah $\mathrm{H}_{0}$ ditolak. Keputusan tersebut dapat dilihat dari nilai statistik hitung lebih besar dari tabel statistik $(55,699>5,991)$.

Perbandingan Koefisien Variasi pada Saham Syariah, Reksadana Syariah, dan Emas Periode 2011-2015

Berdasarkan tabel 4.3 nilai signifikansi koefisien variasi pada JII, reksadana syariah, dan emas sebesar 0,005 lebih kecil dari 0,05. Hal ini menyatakan bahwa koefisien variasi pada JII, reksadana syariah, dan emas terdapat perbedaan yang signifikan.

Statistik hitung atau chi-square sebesar 10,495 dan memiliki derajat kebebasan (df) sebesar 2 dengan tingkat signifikansi sebesar 0,05. Dengan melihat nilai chisquare, derajat kebebasan, dan tingkat signifikansi tersebut maka dalam statistk tabel menunjukkan angka sebesar 5,991. Keputusan uji Kruskal-Wallis dari tingkat pengembalian pada instrumen investasi adalah $\mathrm{H}_{0}$ ditolak. Keputusan tersebut dapat dilihat dari nilai statistik hitung lebih besar dari tabel statistik $(10,495>5,991)$.

\section{Pembahasan}

\section{Tingkat Pengembalian (Return)}

Menurut kesimpulan hasil uji hipotesis Kruskal-Wallis dari tingkat pengembalian (return) pada JII, reksadana syariah, dan emas adalah $\mathrm{H}_{0}$ diterima. Artinya, tidak terdapat perbedaan yang signifikan dari tingkat pengembalian (return) terhadap

JII, reksadana syariah, dan emas. Tidak adanya perbedaan dikarenakan instrumen investasi ini memiliki karakteristik yang sama dimana ketiga instrumen ini berpegang teguh terhadap pedoman syariah untuk memberikan tingkat pengembalian (return) yang sesuai.

Berapapun hasil investasi yang dipeeroleh, Islam mengajarkan pada umatnya untuk tetap mensyukuri atas hasil tersebut. Sebagaimana firman Allah yang tercantum dalam Al-Qur'an surat Ibrahim ayat 10:

"Berkata Rasul-rasul mereka: "Apakah ada keragu-raguan terhadap Allah, Pencipta langit dan bumi? Dia menyeru kamu untuk memberi ampunan kepadamu dari dosadosamu dan menangguhkan (siksaan)mu sampai masa yang ditentukan?" mereka berkata: "Kamu tidak lain hanyalah manusia seperti Kami juga. kamu menghendaki untuk menghalang-halangi (membelokkan) Kami dari apa yang selalu disembah nenek moyang Kami, karena itu datangkanlah kepada Kami, bukti yang nyata". (QS. 14:10, Departemen Agama Rl, 1997:381)

Menurut Al- Mahalli (2000:197) tentu tidak ada keraguan didalam mentauhidNya mengingat adanya bukti-bukti jelas menunjukkan ke arah yang menciptakan supaya taat kepada-Nya. Karena sesungguhnya Islam itu menghapus semua dosa mengecualikan dosa-dosa yang menyangkut hak hambahambaAllah. Tidak lain yaitu berhalaberhala sesembahan mereka yang jelas untuk membuktikan kebenaran kalian itu. 
Fitri, et al/Jurnal Ekonomi Syariah Teori dan Terapan Vol. 5 No.6 Juni 2018: 483-497; PENENTUAN INVESTASI BERDASARKAN TINGKAT RISIKO PADA SAHAM SYARIAH, REKSADANA SYARIAH, DAN EMAS PERIODE 2011-2015

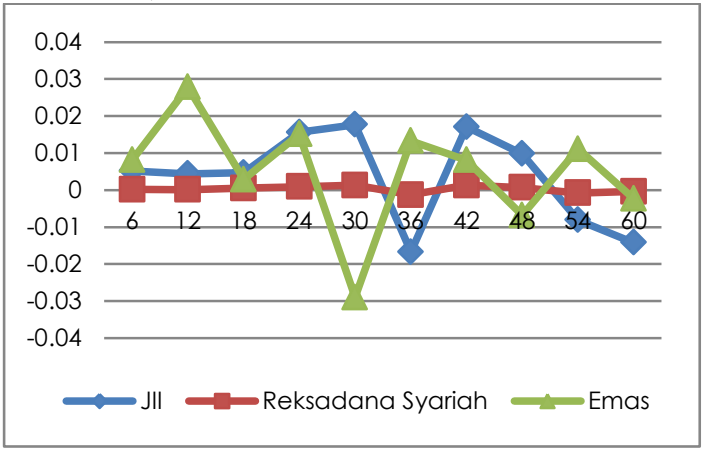

Sumber: Data diolah

Gambar 4.1

Pergerakan Tingkat Pengembalian (Return) pada JII, Reksadana Syariah, dan Emas Periode 2011-2015

Pergerakan tingkat pengembalian (return) pada gambar 4.1 menunjukkan hasil dari penelitian ini tidak terdapat perbedaan yang signifikan antara tingkat pengembalian (return) pada JII, reksadana syariah, dan emas periode 2011-2015. Sehingga peelitian ini selaras dengan penelitian sebelumnya. Hasil penelitian yang dilakukan oleh Yazir dan Suhardi (2014) menunjukkan perhitungan † sebesar 1,916 dengan nilai signifikan sebesar 0,081 dimana nilai tersebut diatas level signifikan 0,05. Hasil tersebut membuktikan bahwa tidak terdapat perbedaan yang signifikan antara tingkat pengembalian (return) JII dengan tingkat pengembalian (return) reksadana syariah.

\section{Risiko}

Menurut uji hipotesis pada tabel 4.3 risiko pada JII, reksadana syariah, dan emas menyatakan $\mathrm{H}_{0}$ ditolak. Artinya, terdapat perbedaan yang signifikan dari tingkat pengembalian (return) terhadap JII, reksadana syariah, dan emas. Terdapat perbedaan yang signifikan risiko pada instrumen investasi sesuai pernyataan diatas bahwa JII memiliki risiko baik secara sistematis maupun tidak sistematis tanpa adanya campurtangan dari manajer investasi (Tandelilin, 2010:104). Pada reksadana syariah, risiko yang terjadi pada NAB dipengaruhi dari harga efek yan tersusun dalam portofolionya (menurunnya NAB) dan risiko likuiditas yang bisa menyulitkan manajemen perusahaan dalam menyediakan dananya (Achsien, 2000:82). Menurut Oei (2009:65) pada investasi emas berpeluang mengalami penurunan harga, rentangdalam kasus pencurian, rentang dalam selisih harga jual dan beli.

Ketidakpastian muncul karena dalam investasi terdapat perencanaan yang mengalami kerugian atau keuntungan. Sebagaimana firman Allah dalam Surat Luqman ayat 34 :

"Sesungguhnya Allah, hanya pada sisiNya sajalah pengetahuan tentang hari Kiamat; dan Dia-lah yang menurunkan hujan, dan mengetahui apa yang ada dalam rahim. dan tiada seorangpun yang dapat mengetahui (dengan pasti) apa yang akan diusahakannya besok[1 187]. dan tiada seorangpun yang dapat mengetahui di bumi mana Dia akan mati. Sesungguhnya Allah Maha mengetahui lagi Maha Mengenal". (QS. Departemen Agama RI, 1997:658)

Al-Mahalli (2000:263) menerangkan ayat diatas tentang lima perkara hanya Allah yang tahu dan tidak seorangpun yang mengetahuinya. Lima perkaran tersebut yaitu kapan kiamat akan terjadi, kapan hujan akan turun, apakah laki-laki atau perempuan yang ada di dalam rahim, baik buruknya yang akan terjadi besok, dan hari kiamat. 
Fitri, et al/Jurnal Ekonomi Syariah Teori dan Terapan Vol. 5 No.6 Juni 2018: 483-497; PENENTUAN INVESTASI BERDASARKAN TINGKAT RISIKO PADA SAHAM SYARIAH, REKSADANA SYARIAH, DAN EMAS PERIODE 2011-2015

Adapun kaidah figh pada risiko

Berdasarkan tabel 4.3 terdapat menurut Djazuli (2006:124) sebagai berikut:

\section{Al Ghormu Bïl Ghonmi}

$$
\text { الغَر مُبَا لغَنْم }
$$

"Risiko itu menyertai manfaat"

Maksud dari kaidah tersebut adalah return yang diperoleh harus sebanding dengan risiko yang didapat pada kerugian atas aset. Kata lain, "high risk high return" yang artinya tingginya suatu risiko juga akan meningkatkan tingkat pengembalian (return). Berikut ini merupakan pergerakan risiko pada JII, reksadana syariah, dan emas periode 2011-2015.

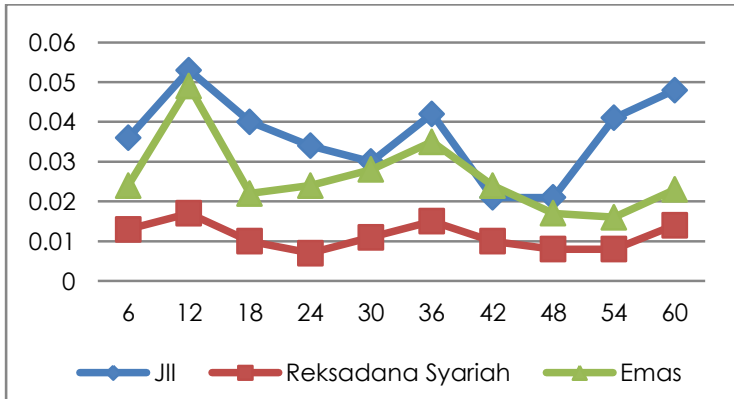

sumver: vala alotan

Gambar 4.2

Pergerakan Risiko pada JII, Reksadana Syariah, dan Emas Periode 2011-2015

Pergerakan risiko pada gambar 4.2 menunjukkan hasil dari penelitian ini terdapat perbedaan yang signifikan antara risiko pada JII, reksadana syariah, dan emas. Sehingga pada penelitian ini sesuai dengan hasil dari penelitian sebelumnya Yazir dan Suhardi (2013) menunjukkan perhitungan $\dagger$ sebesar $-7,849$ dengan nilai signifikan sebedar 0,000 dimana nilai tersebut diatas level signifikan 0,05 . Hasil tersebut membuktikan bahwa terdapat perbedaan yang signifikan antara risiko Jll dengan reksadana syariah. perbedaan risiko pada JII reksadana syariah, dan emas maka dilakukan uji Mann-Whitney.

Tabel 4.4

Uji Mann-Whitney

Risiko dan Koefisien Variasi pada JII, Reksadana Pesona Syariah, dan Emas

\begin{tabular}{|c|c|c|c|c|}
\hline & $\begin{array}{l}\text { Instrumen } \\
\text { Investasi }\end{array}$ & $\begin{array}{l}\text { Mean } \\
\text { Rank }\end{array}$ & Sig. & Keterangan \\
\hline \multirow{6}{*}{ Risiko } & JII & 84,19 & \multirow[b]{2}{*}{0,000} & \multirow[b]{2}{*}{$\begin{array}{c}\text { Ho ditolak } \\
\text { (Terdapat } \\
\text { perbedaan) }\end{array}$} \\
\hline & $\begin{array}{c}\text { Reksadana } \\
\text { Pesona } \\
\text { Syariah }\end{array}$ & 36,81 & & \\
\hline & JII & 69,89 & \multirow[b]{2}{*}{0,003} & \multirow{2}{*}{$\begin{array}{c}\text { Ho ditolak } \\
\text { (Terdapat } \\
\text { perbedaan) }\end{array}$} \\
\hline & Emas & 51,11 & & \\
\hline & $\begin{array}{c}\text { Reksadana } \\
\text { Pesona } \\
\text { Syariah }\end{array}$ & 46,69 & \multirow[t]{2}{*}{0,000} & \multirow{2}{*}{$\begin{array}{c}\mathrm{H}_{0} \text { ditolak } \\
\text { (Terdapat } \\
\text { perbedaan) }\end{array}$} \\
\hline & Emas & 74,31 & & \\
\hline \multirow{6}{*}{$\begin{array}{c}\text { Koefisien } \\
\text { Variasi }\end{array}$} & JII & 51,55 & \multirow[b]{2}{*}{0,005} & \multirow[b]{2}{*}{$\begin{array}{c}\text { Ho ditolak } \\
\text { (Terdapat } \\
\text { perbedaan) }\end{array}$} \\
\hline & $\begin{array}{c}\text { Reksadana } \\
\text { Pesona } \\
\text { Syariah } \\
\end{array}$ & 69,45 & & \\
\hline & JII & 65,28 & \multirow[b]{2}{*}{0,133} & \multirow{2}{*}{$\begin{array}{c}\text { Ho diterima } \\
\text { (Tidak } \\
\text { terdapat } \\
\text { perbedaan) }\end{array}$} \\
\hline & Emas & 55,72 & & \\
\hline & $\begin{array}{c}\text { Reksadana } \\
\text { Pesona } \\
\text { Syariah }\end{array}$ & 68,62 & \multirow[t]{2}{*}{0,011} & \multirow[t]{2}{*}{$\begin{array}{c}\text { Ho ditolak } \\
\text { (Terdapat } \\
\text { perbedaan) }\end{array}$} \\
\hline & Emas & 52,38 & & \\
\hline
\end{tabular}

Sumber: Data diolah

\section{Koefisien Variasi}

Menurut uji hipotesis pada tabel 4.2 keimpulan dari koefisien variasi pada JII, reksadana syariah, dan emas adalah $\mathrm{H}_{0}$ ditolak. Artinya, terdapat perbedaan signifikan antara koefisien variasi pada JII, reksadana syariah, dan emas.

Adanya perbedaan yang signifikan disebabkan karena hasil uji hipotesis dari risiko juga dinyatakan terdapat perbedaan yang signifikan sehingga berdampak pada koefisien variasi terhadap instrumen investasi ini. Sesuai dengan yang dijelaskan oleh Horne dan Wachowicz (2007:79) menyatakan bahwa ukuran penyimpangan relatif dari suatu distribusi sebagai rasio standar deviasi dengan nilai yang diperkirakan untuk nilai 
Fitri, et al/Jurnal Ekonomi Syariah Teori dan Terapan Vol. 5 No.6 Juni 2018: 483-497; PENENTUAN INVESTASI BERDASARKAN TINGKAT RISIKO PADA SAHAM SYARIAH, REKSADANA SYARIAH, DAN EMAS PERIODE 2011-2015

distribusi tersebut (tingkat keuntungan

dengan emas yaitu ( $\mathrm{H}_{0}$ ditolak) yang diharapkan).

Pergerakan koefisien variasi pada gambar 4.3 menunjukkan hasil dari penelitian ini terdapat perbedaan yang signifikan antara koefisien variasi pada JII, reksadana syariah, dan emas. Perhitungan koefisien variasi ini digunakan untuk melihat seberapa baik risiko tersebut. Jika semakin kecil koefisien variasi, menunjukkan semakin kecil risiko dan semakin besar return ekspektasi.

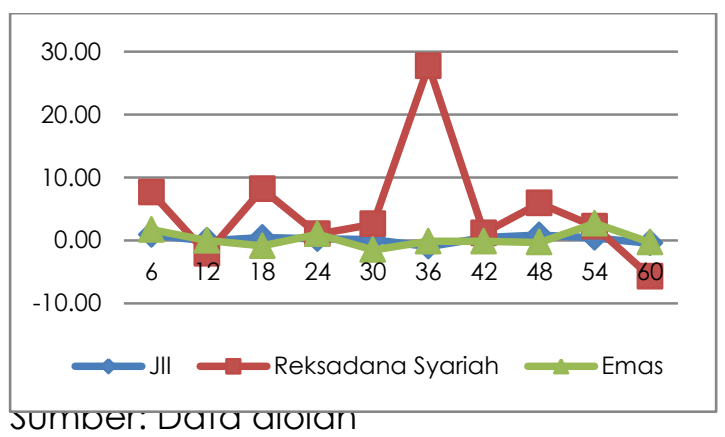

Gambar 4.3

Pergerakan Risiko pada JII, Reksadana Syariah, dan Emas Periode 2011-2015

\section{SIMPULAN DAN SARAN}

\section{Simpulan}

Berdasarkan hasil analisis dan pembahasan pada penelitian yang dilakukan dapat disimpulkan:

1. Menggunakan uji Kruskal-Wallis menyatakan terdapat perbedaan yang signifikan antara tingkat risiko pada saham syariah, reksadana syariah, dan emas. Masing-masing dari pengujian penelitian ini menggunakan tingkat signifikan sebesar 0,05.

2. Menggunakan uji lanjut Mann Whitney dapat diambil kesimpulan bahwa risiko pada saham syariah dengan reksadana syariah, saham syariah dengan emas, dan reksadana syariah terdapat perbedaan satu sama lain. Sedangkan untuk koefisien variasi pada saham syariah dengan reksadana syariah dan reksadana syariah dengan emas yaitu $\mathrm{H}_{0}$ ditolak. Namun pada saham syariah dengan emas tidak terdapat perbedaan.

3. Berdasarkan hasil rata-rata bahwa emas memiliki return lebih tinggi dibandingkan saham syariah dan reksadana syariah. Sedangkan saham syariah memiliki risiko yang lebih tinggi dibandingkan emas dan reksadana syariah. Namun dalam segi koefisien variasi, saham syariah merupakan instrumen investasi yang paling baik dibandingkan emas dan reksadana syariah.

\section{Saran}

1. Bagi investor

a. Risk Seeker

Investor yang menyukai risiko lebih tinggi dibandingkan return harapan maka instrumen investasi yang cocok pada tipe ini yaitu saham syariah.

b. Risk Moderate

Untuk investor yang menyukai risiko dan return harapan sama maka instrumen investasi yang cocok pada tipe ini yaitu emas.

c. Risk Averse

Sedangkan bagi investor yang menyukai risiko lebih rendah dibandingkan return harapan maka instrumen investasi yang 
Fitri, et al/Jurnal Ekonomi Syariah Teori dan Terapan Vol. 5 No.6 Juni 2018: 483-497; PENENTUAN INVESTASI BERDASARKAN TINGKAT RISIKO PADA SAHAM SYARIAH, REKSADANA SYARIAH, DAN EMAS PERIODE 2011-2015

cocok pada tipe ini yaitu reksadana syariah.

2. Bagi penelitian mendatang Bagi penelitian selanjutnya disarankan untuk megembangkan penelitian ini dengan berbagai macam variasi variabel dan periode berrbeda. Misalnya, perbandingan berbagai macam instrumen investasi berdasarkan tingkat risiko.

\section{DAFTAR PUSTAKA}

Abdullah, Yatimin.2006. Studi Islam Kontemporer. Cetakan 1. Jakarta: Amzah.

Achsien, Iggi H. 2000. Investasi Syariah di Pasar Modal, Menggagas Konsep dan Praktek Manajemen Portofolio Syariah. Edisi Pertama, Jakarta: PT. Gramedia Utama.

Al-Qarafi, 2009. Anwar Al-Buruq fi Anwa'AlFaruq. Juz 2. Lebanon: Darul Kutub AlIlmiyah.

Brigham, F. Eugene dan Joel F. Houston. 2001. Dasar-dasar Manajemen Kevangan. Edisi Delapan. Jakarta: Salemba Empat. 2006. Dasar-dasar Manajemen Keuangan. Edisi sepuluh. Jakarta: Salemba Empat.

Departemen Agama RI. 1971. Al-Qur'an dan Terjemahnya. Jakarta: Yayasan Penyelenggara

Penterjemah/Penafsiran Al-Qur'an.

Dewan Syariah Nasional. 2000. Fatwa DSNMUI No. 20/DSN-MUI/IX/2000 tentang Kondisi Emiten yang Tidak Layak. (Online) www.bapepam.com diakses pada tanggal 18 September 2016.

Fatwa DSN-MUI 40/DSN-
MUI/X/2002 tentang Kriteria Emiten
atau Perusahaan Publik. (Online)
www.bapepam.com diakses pada
tanggal 6 November 2016.

. Fatwa DSN-MUI No. 77/DSNMUI/VI/ 2010 tentang Jual-Beli Emas Secara Tidak Tunai. (Online) www.babpepam.com diakses pada tanggal 6 November 2016.

Diantoro, Yimi. 2010. Emas Investasi \& Pengolahannya. Jakarta: PT Gramedia Pusaka Utama.

Dipraja, Sholeh. 2011. Siapa Bilang Investasi Emas Butuh Modal Gede? (Rp 200 Ribu Bisa Kok!). Jakarta: Tangga Pustaka.

Djazuli, A. 2006. Kaidah-Kaidah Fikih: Kaidah-Kaidah Hukum Islam dalam Masalah-Masalah yang Praktis. Jakarta: Kencana.

Guinan, Jack.2010. Investopedia: Cara Mudah Memahami Istilah Investasi. Jakarta: Hikmah (PT Miza Publika).

Halim, Abdul. 2005. Analisis Investasi. Edisi Kedua. Jakarta: Salemba Empat.

Handayani, Sri. 2010. Cerdik Mengelola Gaji: Rahasia Karyawan Kaya Raya. Yogyakarta: BPFE.

Hartono, Jogiyanto. 2013. Teori Portofolio dan Analisis Investasi. Edisi Kedelapan. Yogyakarta: BPFE.

Hidayat, Taufik. 2011. Kaya Sekarang Juga! Cara Pintar Investasi Emas \& Dinar. Cetakan Pertama. Jakarta: Mediakita. 
Fitri, et al/Jurnal Ekonomi Syariah Teori dan Terapan Vol. 5 No.6 Juni 2018: 483-497; PENENTUAN INVESTASI BERDASARKAN TINGKAT RISIKO PADA SAHAM SYARIAH, REKSADANA SYARIAH, DAN EMAS PERIODE 2011-2015

Horne, James C. Van dan John $M$. Wachowicz. 2007. Prinsip-prinsip Manajemen Kevangan, Terjemahan Dewi Fitriasari dan Deny Arnos Kwary. Edisi 12. Jakarta: Salemba Empat.

Hudaya, Amim dan Natali Yustisia. 2013.

Analisis Perbandingan Kinerja Emas dengan Indeks Harga Saham Gabungan (IHSG). (Online), (http://hdl.handle.net/123456789/1340, Diakses 27 Maret 2017)

Imam, Nofie. 2008. Memulai Investasi

Reksadana. Jakarta: PT Elex Media Komputindo.

Judisseno, Rimsky K. 2005. Sistem Moneter dan Perbankan di Indonesia. Jakarta:

PT Gramedia Pusaka Utama.

Oei, Istijanto. 2009. Kiat Investasi Valas,

Emas, Saham. Jakarta: PT Gramedia Pustaka Utama.

Salim, Joko. 2010. Jangan Investasi Emas Sebelum Membaca Buku Ini!. Cetakan Pertama. Jakarta: Visimedia.

Simamora, Henry. 2000. Akuntansi Basis Pengembalian Keputusan Bisnis. Jakarta: Salemba Empat.

Sugiyono. 2011. Statistik untuk Penelitian. Bandung: CV Alfabeta.

Sunariyah. 2003. Pengantar Pengetahuan Pasar Modal. Edisi Ketiga. Yogyakarta: UPP-AMP YKPN.

Tandelilin, Eduardus. 2001. Analisis Investasi dan Manajemen Portofolio Edisi. Pertama. Yogyakarta: BPFE Yogyakarta.

\footnotetext{
---------. 2010. Portofolio dan Investasi Teori dan Aplikasi. Edisi Pertama. Yogyakarta: Kanisius.
}

Tanuwidjaja, William. 2009. Cerdas Investasi Emas. Cetakan Pertama. Yogyakarta: Medpress (Anggota IKAPI).

www.bapepam.com, diakses pada tanggal 18 September 2016.

www.goldprice.org, diakses pada tanggal 6 November 2016.

www.harga-emas.org, diakses pada tanggal 29 November 2016.

www.idx.go.id, diakses pada tanggal 29 November 2016.

www.kitco.com, diakses pada tanggal 29 November 2016.

Yazir, Abdul Gani dan Suhardi. 2013. Analisis Perbandingan Risiko dan Tingkat Pengembalian Reksdana Syariah dan Reksadana Konvensional. Jurnal Akuntansi. I (1): 9. 